18. Wadsworth SJ, Nijmeh HS, Hall IP. Glucocorticoids increase repair potential in a novel in vitro human airway epithelial wounding model. J Clin Immunol 2006;26:376-87.

19. O'Byrne PM. Global guidelines for asthma management: summary of the current status and future challenges. Pol Arch Med Wewn 2010;120:511-17.

20. Kobayashi H, Ohi H, Sugimura M, et al. Inhibition of in vitro ovarian cancer cell invasion by modulation of urokinase-type plasminogen activator and cathepsin B. Cancer Res 1992:52:3610-14.

21. Ghosh S, Johnson JJ, Sen R, et al. Functional relevance of urinary-type plasminogen activator receptor-alpha3beta1 integrin association in proteinase regulatory pathways. J Biol Chem 2006;281:13021-9.

22. Legrand C, Polette M, Tournier JM, et al. uPA/plasmin system-mediated MMP-9 activation is implicated in bronchial epithelial cell migration. Exp Cell Res 2001;264:326-36.

23. Xiao W, Hsu YP, Ishizaka A, et al. Sputum cathelicidin, urokinase plasminogen activation system components, and cytokines discriminate cystic fibrosis, COPD, and asthma inflammation. Chest 2005:128:2316-26.

24. Chu EK, Cheng J, Foley JS, et al. Induction of the plasminogen activator system by mechanical stimulation of human bronchial epithelial cells. Am J Respir Cell Mol Biol 2006;35:628-38.

25. Gray TE, Guzman K, Davis CW, et al. Mucociliary differentiation of serially passaged normal human tracheobronchial epithelial cells. Am J Respir Cell Mol Biol 1996;14:104-12.

26. Stevens PT, Kicic A, Sutanto EN, et al. Dysregulated repair in asthmatic paediatric airway epithelial cells: the role of plasminogen activator inhibitor-1. Clin Exp Allergy 2008;38:1901-10.

27. Mazzieri R, Masiero L, Zanetta L, et al. Control of type IV collagenase activity by components of the urokinase-plasmin system: a regulatory mechanism with cellbound reactants. EMBO J 1997:16:2319-32.
28. Baramova EN, Bajou K, Remacle A, et al. Involvement of PA/plasmin system in the processing of pro-MMP-9 and in the second step of pro-MMP-2 activation. FEBS Lett 1997; 405:157-62.

29. Chen $\mathbf{P}$, Parks WC. Role of matrix metalloproteinases in epithelial migration. J Cell Biochem 2009;108:1233-43.

30. Buisson AC, Zahm JM, Polette $\mathrm{M}$, et al. Gelatinase B is involved in the in vitro wound repair of human respiratory epithelium. J Cell Physiol 1996;166 413-26.

31. Jo M, Thomas KS, O'Donnell DM, et al. Epidermal growth factor receptor-dependent and -independent cell-signaling pathways originating from the urokinase receptor. $J$ Biol Chem 2003;278:1642-6.

32. Gondi CS, Kandhukuri N, Dinh DH, et al. Down-regulation of uPAR and UPA activates caspase-mediated apoptosis and inhibits the PI3K/AKT pathway. Int J Oncol 2007;31:19-27.

33. Dieckgraefe BK, Weems DM, Santoro SA, et al. ERK and p38 MAP kinase pathways are mediators of intestinal epithelial wound-induced signal transduction. Biochem Biophys Res Commun 1997:233:389-94.

34. Sharma GD, He J, Bazan HE. p38 and ERK1/2 coordinate cellular migration and proliferation in epithelial wound healing: evidence of cross-talk activation between MAP kinase cascades. J Biol Chem 2003:278:21989-97.

35. Shetty S, Padijnayayveetil J, Tucker T, et al. The fibrinolytic system and the regulation of lung epithelial cell proteolysis, signaling, and cellular viability. Am J Physiol Lung Cell Mol Physiol 2008;295:L967-75.

36. Kicic A, Hallstrand TS, Sutanto EN, et al. Decreased fibronectin production significantly contributes to dysregulated repair of asthmatic epithelium. Am J Respir Crit Care Med 2010;181:889-98.

37. Mizukami IF, Todd RF 3rd. A soluble form of the urokinase plasminogen activator receptor (suPAR) can bind to hematopoietic cells. J Leukoc Biol 1998:64 203-13.

\title{
Lebrikizumab may benefit a subset of patients with asthma
}

Interleukin 13 (IL-13), a cytokine of type 2 helper T cells, may contribute to the heterogeneity of asthma in terms of clinical course and response to treatment. IL-13 leads to the production of periostin, a protein that may cause airway remodelling.

In this randomised, double-blind, placebo-controlled study, lebrikizumab, a monoclonal antibody that binds to IL-13 thereby inhibiting its function, was used to investigate the effect on patients with uncontrolled asthma undergoing treatment with inhaled steroids. Lebrikizumab showed superior primary outcome to placebo, with an increase in prebronchodilator forced expiratory volume in one second $\left(\mathrm{FEV}_{1}\right)$ by $5.5 \%$ at week 12 . Patients with higher periostin levels had a relative increase in $\mathrm{FEV}_{1}$ of $8.2 \%$ compared with those receiving placebo, whereas the low periostin group had a relative increase in $\mathrm{FEV}_{1}$ of $1.6 \%$ over the placebo group. There was no significant improvement in secondary outcomes including rates of asthma exacerbation, asthma symptom scores or use of rescue medications. The secondary outcome results may have been limited by the study length of 24 weeks. There was definitely a percentage decline in exacerbation rates in the lebrikizumab group in patients with high Th2, periostin and fraction of exhaled nitric oxide values but these were not statistically significant.

This study shows the potential use of biomarkers to target specific patients with asthma who would benefit from treatment. Further multicentre studies using larger numbers of patients over a greater time period should be conducted to confirm and expand on the results of the current study.

- Corren J, Lemanske RF, Hanania NA, et al. Lebrikizumab treatment in adults with asthma. N Engl J Med 2011;365:1088-98.

\section{Sasiharan Sithamparanathan}

Correspondence to Dr Sasiharan Sithamparanathan, ST3, King George Hospital, Barley Lane, Goodmayes, Essex IG3 8YB, UK; sasiharan_9@hotmail.com

Provenance and peer review Not commissioned; internally peer reviewed.

Published Online First 25 November 2011

Thorax 2012;67:487. doi:10.1136/thoraxjnl-2011-201329 